\title{
Analisis Dampak Pengembangan Pelabuhan di Suatu Wilayah: Studi Kasus Terminal Kendal Jawa Tengah
}

\author{
Rafidah Agni, Irwan Tri Yunianto, dan Christino Boyke S.P. \\ Departemen Teknik Transportasi Laut, Fakultas Teknologi Kelautan, \\ Institut Teknologi Sepuluh Nopember (ITS) \\ e-mail: christino.boyke@gmail.com
}

\begin{abstract}
Abstrak-PDRB Jawa Tengah berdasarkan lapangan usaha tahun 2016 menunjukkan sektor industri pengolahan memiliki kontribusi terbesar dan terus mengalami kenaikan 4,3\%. Untuk meningkatkan perekomian, Kementrian Perindustrian merencanakan pengembangan zona industri. Sehingga diperlukan infrastruktur transportasi sebagai penunjang kegiatan industri. Pelabuhan Tanjung Emas merupakan pelabuhan yang sangat berperan di Jawa Tengah dimana $47 \%$ total arus muatan Jawa Tengah melalui Pelabuhan Tanjung Emas pada tahun 2016. Di sisi lain Terminal Kendal saat ini sedang dalam pengembangan yang direncanakan menjadi penunjang Pelabuhan Tanjung Emas. Tugas akhir ini bertujuan untuk mengetahui kondisi eksisting muatan peti kemas dan curah kering di Jawa Tengah dan Pelabuhan Tanjung Emas serta mengetahui dampak Terminal Kendal terhadap zona industri di Jawa Tengah. Hasil analisis menunjukkan bahwa jumlah peti kemas di Jawa Tengah tahun 2016 sebesar $67 \%$ dan curah kering 12\%. Sedangkan di Pelabuhan Tanjung Emas jumlah peti kemas tahun 2016 sebesar $61 \%$ dan muatan curah kering sebesar $19 \%$. Kemudian untuk mengetahui dampak Terminal Kendal terhadap zona industri dilakukan analisis biaya transportasi menggunakan 3 skenario. Hasil analisis menunjukkan bahwa Terminal Kendal tidak memberikan dampak terhadap zona industri dengan skenario 1 dan 2. Sedangkan dengan menggunakan skenario 3, Terminal Kendal memberikan dampak penurunan biaya transportasi yaitu untuk muatan curah kering tujuan Kabupaten tegal terjadi penurunan biaya sebesar $4 \%$ dan untuk muatan peti kemas terjadi penurunan $9 \%$ terhadap zona industri di Kabupaten Banyumas, Kabupaten Batang, Kabupaten Brebes, Kabupaten Kendal, Kabupaten Pekalongan, Kabupaten Pemalang, Kabupaten Purbalingga, Kabupaten Tegal, Kabupaten Temanggung, dan Kabupaten Wonosobo.
\end{abstract}

Kata Kunci-Biaya Transportasi, Industri, Terminal Kendal, Pelabuhan Tanjung Emas.

\section{PENDAHULUAN}

$\mathrm{P}$ ADA tahun 2016 Provinsi Jawa Tengah berada pada posisi keempat dalam kontribusi PDB atas harga konstan berdasarkan provinsi yaitu dengan kontribusi sebesar $9 \%$. PDRB Jawa Tengah sendiri berdasarkan lapangan usaha tahun 2016 menunjukkan beberapa sektor yang memiliki kontribusi besar terhadap PDRB Jawa Tengah dimana sektor yang memberikan kontribusi terbesar adalah sektor industri pengolahan dengan kontribusi 34,9\% [1]. Bersamaaan dengan hal tersebut, Kementrian Perindustrian merencanakan pengembangan zona industri untuk menunjang program percepatan petumbuhan ekonomi nasional.

Untuk menunjang kegiatan perindustrian maka dibutuhkan infrastruktur penunjang kegiatan industri, salah satunya adalah infrastrukur transportasi. Pelabuhan Tanjung Emas merupakan pelabuhan yang memiliki peran penting dalam pertukaran arus barang di Jawa Tengah. Sebesar $47 \%$ arus muatan Jawa Tengah melalui Pelabuhan Tanjung Emas.

Di sisi lain, saat ini sedang dilakukan pengembangan sebuah pelabuhan yaitu Terminal Kendal yang berada dalam satu wilayah DLKr dan DLKP dengan Pelabuhan Tanjung Emas. Terminal Kendal ini direncanakan menjadi pelabuhan penunjang dari Pelabuhan Tanjung Emas [2]. Sehubungan peran Pelabuhan Tanjung Emas terhadap industri di Jawa Tengah serta rencana pengembangan Terminal Kendal sebagai pelabuhan penunjang Pelabuhan Tanjung Emas, maka dapat dirumuskan permasalahan yaitu mengenai bagaimana kondisi eksisting muatan zona industri dan bagaimana dampak pengembangan Terminal Kendal terhadap biaya transportasi industri di Jawa Tengah. Dengan menganalisis biaya transportasi industri melalui Terminal Kendal maka dapat diketahui apakah Terminal Kendal memilik hinterland di Jawa Tengah dan seberapa besar dampak yang diberikan tehadap biaya transportasi yang ditanggung oleh industri.

\section{METODE PENELITIAN}

\section{A. Tahap Identifikasi Permasalahan}

Pada tahap ini dilakukan identifikasi terhadap permasalahan mengenai pembangunan dan pengembangan industri di Jawa Tengah serta rencana pengembangan Terminal Kendal. Berdasarkan identifikasi permasalahan, didapatkan bahwa perlu untuk mengetahui kondisi eksisting dari muatan di Jawa Tengah dan zona industri serta mengetahui bagaimana dampak pengembangan Terminal Kendal terhadap biaya transportasi zona industri di Jawa Tengah

\section{B. Pengumpulan Data}

Terdapat beberapa data yang dibutuhkan untuk analisis jumlah muatan dan analisis biaya transportasi laut. Data yang dibutuhkan antara lain

1. Data Angkutan Laut : spesifikasi kapal \& permesinan

2. Data Angkutan Darat 
Jarak antara pelabuhan asal dan pelabuhan tujuan Spesifikasi moda angkutan darat

3. Data Pelabuhan

Fasilitas pelabuhan

Tarif layanan pelabuhan

Jarak antara pelabuhan asal dan pelabuhan tujuan Arus Barang

4. Data Industri : proporsi luas area industri

\section{Analisis Kondisi Eksisting}

Dalam penelitian ini dilakukan analisis kondisi eksisting terhadap objek penelitian yang diantaranya adalah:

1. Jumlah Kapal, Jumlah Muatan, Historis Kedatangan Kapal

Analisis tersebut dilakukan untuk mengetahui tren muatan dan kedatangan kapal di pelabuhan tanjung emas. Selain itu historis kedatangan kapal akan digunakan sebagai dasar penetapan kluster kapal.

2. Kapasitas Pelabuhan Pelabuhan Tanjung Emas Kapasitas Pelabuhan Tanjung Emas digunakan untuk mengetahui berapa batas kemampuan pelabuhan untuk menangani arus muatan dari zona industri.

3. Produksi Muatan Zona Industri.

Analisis ini dilakukan untuk mengetahui jumlah muatan industri yang akan menjadi potensi muatan Pelabuhan Tanjung Emas dan Terminal Kendal

Kapasitas Pelabuhan Tanjung Emas dan produksi muatan industri saling berhubungan. Jumlah arus muatan yang dapat dilayani oleh Pelabuhan Tanjung Emas selain bergantung dengan biaya transportasi yang ditanggung industri juga dipengaruhi oleh kapasitas dari pelabuhan itu sendiri.

\section{Analisis Dampak Biaya Transportasi Industri}

Terdapat beberapa tahap dalam analisis dampak biaya transportasi industri yang diantaranya adalah

1. Perhitungan Biaya Transportasi Darat

Perhitungan biya transportasi darat dari Terminal

Kendal dan Pelabuhan Tanjung Emas ke masing-masing zona industri di Jawa Tengah

2. Perhitungan Biaya Transportasi Laut

Perhitungan biaya transportasi laut dari pelabuhan asal ke masing-masing Terminal Kendal dan Pelabuhan Tanjung Emas. Pelabuhan asal yang digunakan dalam penelitian ini adalah pelabuhan banjarmasin, pontianak, balikpapan, dan bima dengan masing-masing variasi jarak pelabuhan asal ke tujuan berturut-turut sekitar $600 \mathrm{~nm}, 800 \mathrm{~nm}, 1090 \mathrm{~nm}$, dan $1040 \mathrm{~nm}$.

Perhitungan biaya transportasi lau dilakukan dengan menggunakan 3 skenario. Secara umum skenario 1 adalah skenario pengiriman muatan peti kemas dan curah kering melalui Terminal Kendal dan Pelabuhan Tanjung Emas dengan kondisi eksisting. Untuk skenario 2 adalah skenario pengiriman muatan curah kering hanya melalui Terminal Kendal, sedangkan untuk muatan peti kemas hanya melalui Pelabuhan Tanjung Emas, dengan kondisi eksisting. Terminal jumlah dan skenario adalah pada pola pengirim spesifikasi skenario 1 dijelaskan pada tabel berikut
Tabel 1.

Perbandingan Spesifikasi Pelabuhan Skenario 1

\begin{tabular}{|c|c|c|c|}
\hline No & Perbandingan & Terminal Kendal & $\begin{array}{c}\text { Pelabuhan } \\
\text { Tanjung Emas }\end{array}$ \\
\hline 1 & Sarat Pelabuhan & $5 \mathrm{~m}$ & $12 \mathrm{~m}$ \\
\hline 2 & Muatan & $\begin{array}{l}\text { Curah Kering } \\
\text { (CK) } \\
\text { Peti Kemas } \\
(\mathrm{PK})\end{array}$ & $\begin{array}{l}\text { Curah Kering } \\
\text { (CK) } \\
\text { Peti Kemas } \\
\text { (PK) }\end{array}$ \\
\hline 3 & $\begin{array}{l}\text { Alat Bongkar } \\
\text { Muat, } \\
\text { Produktivitas }\end{array}$ & $\begin{array}{l}\text { CK: } \\
\text { Escavator, } 87 \\
\text { ton/jam } \\
\text { PK: Crane } \\
\text { Kapal, 15 } \\
\text { Box/jam } \\
\end{array}$ & $\begin{array}{l}\text { CK: Luffing } \\
\text { Crane, } 100 \\
\text { ton/jam } \\
\text { PK: Crane } \\
\text { Kapal, 25 } \\
\text { Box/jam } \\
\end{array}$ \\
\hline 4 & Tarif Pelabuhan & $\begin{array}{l}\text { Tarif Pelabuhan } \\
\text { Sinabang, } \\
\text { Simeulue, Aceh }\end{array}$ & $\begin{array}{l}\text { Tarif Pelabuhan } \\
\text { Tanjung Emas }\end{array}$ \\
\hline
\end{tabular}

Skenario 2 dan Skenario 1 pada dasarnya sama, namun pada skenario 2 muatan peti kemas hanya dilayani di Pelabuhan Tanjung Emas sedangkan muatan curah kering hanya dilakukan di Terminal Kendal. Skenario 2 ini merupakan skenario yang timbul dikarenakan sifat muatan curah kering dan peti kemas yang berbeda dimana pengangkutan muatan peti kemas dapat dilakukan bersamaan dalam satu kapal peti kemas yang sama karena tipe muatan yang sama sehingga muatan yang diangkut dapat semakin banyak, oleh karena itu pelabuhan dengan sarat terbesar dianggap paling menguntungkan karena dapat dimasuki oleh kapal yang besar. Berbeda dengan muatan curah kering yang hanya mengangkut satu tipe muatan saja.

Kemudian untuk skenario 3 adalah skenario dimana kedalaman, tarif layanan, jenis, jumlah, dan produktivitas alat bongkar muat Terminal Kendal sama dengan Pelabuhan Tanjung Emas. Dalam skenario ini dilakukan perbandingan biaya transportasi apabila Terminal Kendal memiliki kapasitas yang sama dengan Pelabuhan Tanjung Emas dan hanya dibedakan oleh jarak antara zona industri dan pelabuhan asal.

3. Perhitungan Biaya Satuan

Biaya satuan transportasi dari pelabuhan ke zona industri tujuan akan menentukan hinterland dari masingmasing pelabuhan. Pelabuhan yang menimbulkan biaya transportasi paling kecil akan menjadi pelabuhan yang digunakan industri untuk melakukan pengiriman barang. Dengan diketahui hinterland dari masing-masing pelabuhan, maka dapat diketahui apakah Terminal Kendal memiliki hinterland dan seberapa besar biaya transportasi yang dapat diturunkan dibandingkan melakukan pengiriman melalui Pelabuhan Tanjung Emas.

\section{KONSEP DAN URAIAN PENELITIAN}

\section{A. Perhitungan Produksi Muatan Industri}

Data proporsi muatan luas area industri digunakan untuk menghitung jumlah muatan zona industri. Bangkitan (produksi) dan tarikan muatan zona industri didapatkan dari perkalian luas area industri dengan tetapan bangkitan dan 
tarikan muatan. ketetapan bangkitan dan tarikan muatan berturut-turut adalah sebesar 3,5 TEUs/bulan/Ha dan 3,0 TEUs/bulan/Ha [3]. Dalam penelitian ini, muatan curah kering akan diasumsikan memiliki berat sebesar 20 ton per TEUs, sedangkan untuk muatan peti kemas diasumsikan memiliki berat 15 ton per TEUs nya.

\section{B. Konsep Biaya Transportasi Darat}

Komponen biaya trasportasi darat adalah biaya tetap, biaya operasional, dan biaya overhead. Biaya tetap adalah biaya yang akan tetap dikeluarkan oleh pengirim barang saat keadaan operasional maupun dalam keadaan non operasional. Biaya operasional adalah biaya yang dikeluarkan karena kegiatan operasional. Biaya overhead adalah biaya tidak langsung seperti biaya peralatan cadangan dan biaya cadangan tenaga kerja yang diperlukan untuk menjalankan kendaraan yang efisien.

Biaya kapital dalam biaya transportasi darat adalah biaya sewa angkutan darat dikalikan dengan lama sewa. Lama sewa kendaraan didapatkan dari waktu perjalanan dari asal ke tujuan kemudian dikalian dengan jumlah roundtrip yang dilakukan kendaran.

Komponen dari biaya operasional adalah biaya bahan bakar, biaya oli dan pelumas, serta biaya perawatan dan perbaikan. Biaya total bahan bakar didapatkan dengan membagi jarak dengan rasio pemakaian bahan bakar, kemudian dikalikan dengan harga bahan bakar tersebut. sedangkan biaya oli dan pelumas serta biaya perawatan dan perbaikan adalah sebesar $5 \%$ dari biaya bahan bakar [4].

Kemudian untuk komponen dari biaya overhead adalah biaya gaji pegawai, biaya administrasi, biaya cadangan, dan biaya asuransi. Biaya overhead adalah sebesar 13\% dari biaya kapital [4]. Penjumlahan dari ketiga komponen biaya transportasi darat tersebut kemudian dibagi dengan jumlah muatan yang diangkut untuk mendapatkan biaya satuan transportasi darat.

\section{Konsep Biaya Transportasi Laut}

Secara umum biaya transportasi laut terdiri dari Biaya Modal (Capital Cost), Biaya Operasional (Operational Cost), Biaya Pelayaran (Voyage Cost) dan Biaya Bongkar Muat (Cargo Handling Cost). Namun dalam penelitian ini digunakan Time Charter Hire (TCH) yang merupakan biaya sewa kapal. TCH sudah mencakup biaya modal dan biaya operasional, sehingga rumusan biaya transportasi laut adalah sebagai berikut

$$
\begin{aligned}
& \text { KC=TCA+VC+CHC } \\
& \text { Keterangan: } \\
& \text { TC : Total Cost } \\
& \text { TCH : Time Charter Hire } \\
& \text { VC : Voyage Cost } \\
& \text { CHC : Cargo Handling Cost [3] }
\end{aligned}
$$

TCH didapatkan dari mengalikan tarif sewa kapal dengan waktu operasional kapal. Untuk mendapatkan tarif sewa kapal dilakukan regresi data ukuran kapal dan tarif sewa kapal.
Komponen biaya transportasi laut kedua adalah voyage cost. Voyage Cost sendiri terdiri dari biaya bahan bakar dan biaya pelabuhan. Kemudian komponen biaya transportasi darat lainnya adalah cargo handling cost yaitu biaya yang dikeluarkan untuk penanganan muatan di pelabuhan.

\section{Konsep Perhitungan Biaya Satuan Transportasi}

Biaya transportasi darat dan biaya transportasi laut dijumlahkan untuk mendapatkan biaya total pengiriman barang. Kemudian biaya total pengiriman barang dibagi dengan jumlah muatan yang dikirimkan untuk mendapatkan biaya satuan transportasi.

\section{GAMBARAN KONDISI SAAT INI}

\section{A. Perindustrian di Jawa Tengah}

Sektor perindustrian dalam kontribusi PDRB di Jawa Tengah dari tahun 2012 Hingga tahun 2016 memiliki proporsi yang paling besar yaitu sebesar 34,9\%. Zona industri Jawa Tengah berada di hampir seluruh Kabupaten/ Kota sejumlah 28 zona industri dengan total luasan zona industri sebesar 38.327 ha. Industri unggulan di jawa tengah antara lain adalah industri makanan, industri pengolahan kayu, bambu, dan rotan, serta industri tekstil.

Dari segi jarak antara pelabuhan tajung emas dan Terminal Kendal ke maisng-masing zona industri. Pelabuhan Tanjung Emas memiliki lokasi yang strategis karena berdekatan dengan banyak zona industri di Jawa Tengah. Hal tersebut wajar dikarenakan Pelabuhan Tajung Emas sendiri berada di ibukota provinsi Jawa Tengah, dimana merupakan pusat kegiatan

\begin{tabular}{|c|c|c|}
\hline Pelabuhan & $\begin{array}{c}\text { Pelabuhan Tanjung } \\
\text { Emas }\end{array}$ & Terminal Kendal \\
\hline \multirow{2}{*}{ Zona industri } & $\begin{array}{lr}\text { Blora, } & \text { Boyolali, } \\
\text { Cilacap, } & \text { Demak, } \\
\text { Grobogan, } & \text { Jepara, } \\
\text { Karanganyar, } & \text { Klaten, } \\
\text { Kudus, Magelang, Pati, }\end{array}$ & $\begin{array}{lr}\text { Banyumas, } & \text { Batang, } \\
\text { Brebes, } & \text { Kendal, } \\
\text { Pekalongan, Pemalang, }\end{array}$ \\
\hline & $\begin{array}{lr}\text { Rembang, } & \text { Semarang, } \\
\text { Sragen, } & \text { Sukoharjo, } \\
\text { Wonogiri, } & \text { Kota } \\
\text { Salatiga, } & \text { Kota } \\
\text { Semarang } & \\
\end{array}$ & $\begin{array}{l}\text { Purbalingga, Tegal, } \\
\text { Temanggung, } \\
\text { Wonosobo }\end{array}$ \\
\hline
\end{tabular}
perekonomian dan pemerintahan. Berikut daftar zona industri yang berdekatan dengan Pelabuhan Tanjung Emas maupun Terminal Kendal.

Tabel 2.

Jangkauan Pelabuhan Terhadap Zona Industri

\section{B. Pelabuhan Tanjung Emas}

Pelabuhan Tanjung Emas merupakan pelabuhan utama di Provinsi Jawa Tengah yang memiliki peran penting terhadap kegiatan transportasi barang di Provinsi Jawa Tengah. Sebesar 47\% arus muatan jawa tengah melalui Pelabuhan Tanjung Emas. Pelabuhan Tanjung Emas melayani semua jenis barang yaitu peti kemas, curah kering, curah cair, dan general cargo. Dari tahun 2013-2017 muatan peti kemas dan muatan curah kering terus berada pada jumlah muatan terbanyak. Berikut adalah arus muatan Pelabuhan Tanjung Emas tahun 2016 


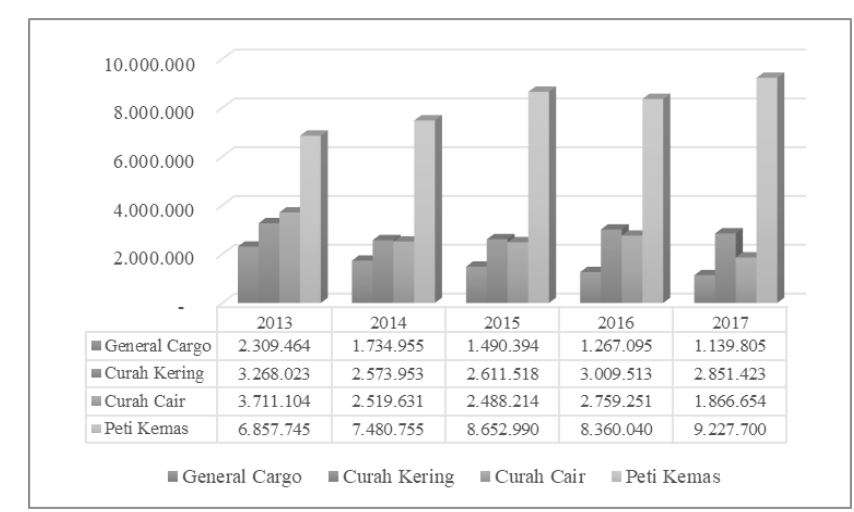

Gambar 1. Arus muatan 2013-2017.

Sama halnya dengan jumlah kedatangan di Pelabuhan Tanjung Emas tahun 2017, kedatangan kapal peti kemas dan curah kering merupakan kedatangan kapal terbanyak dengan proporsi berturut-turut $67 \%$ dan $12 \%$. Berikut adalah gambaran proporsi kedatangan kapal di Pelabuhan Tanjung Emas.

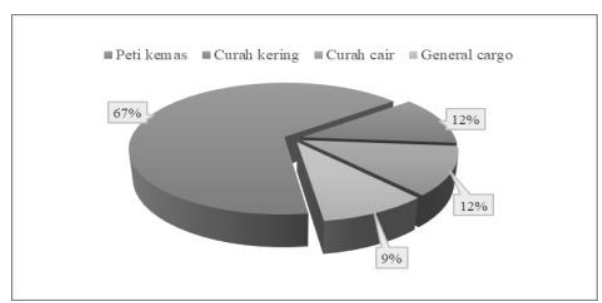

Gambar 2. Proporsi Kedatangan Kapal Tahun 2017.

Untuk melakukan kegiatan operasional, Pelabuhan Tanjung Emas memiliki beberapa fasilitas utama yang salah satunya adalah dermaga, alat bongkar muat, dan lapangan penumpukan. Kedalaman maksimal Pelabuhan Tanjung Emas adalah sebesar $12 \mathrm{~m}$. Alat bongkar peti kemas di Pelabuhan Tanjung Emas adalah Rubber Tyred Gantry sebanyak 23 unit dan untuk curah kering adalah Luffing Crane sebanyak 2 unit.

\section{Terminal Kendal}

Terminal Kendal baru beroperasi tahun 2016 dan saat ini baru melayani kapal penyeberangan Ferry tujuan Karimunjawa dan kapal Ferry Ro-Ro tujuan Pelabuhan Kumai, Kabupaten Kotawaringin Barat. Berikut adalah arus barang di Terminal Kendal tahun 2016-2017

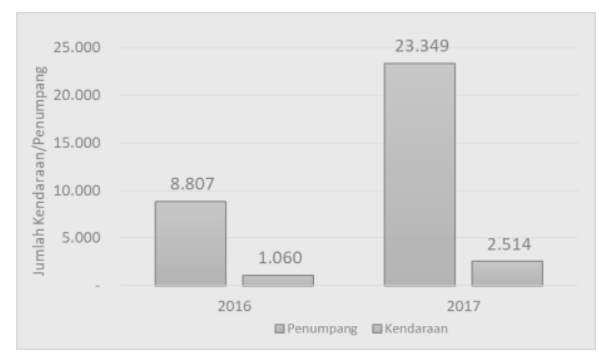

Gambar 3. Arus Barang Terminal Kendal.

Dalam rencana jangka panjang yang dituliskan pada Rencana Induk Pelabuhan Tanjung Emas tahun 2013, Terminal Kendal akan dikembangkan sebagai terminal yang melayani muatan $\log$, batubara, dan curah cair [1]. Untuk mendukung kegiatan operasional, Terminal Kendal memiliki fasilitas darat dan fasilitas laut yang diantaranya alur pelayaran, dermaga, dan kolam pelabuhan. Kedalaman area alur pelayaran Terminal Kendal yang berada di luar breakwater berkisar antara -3,5 m LWS hingga -8,9 m LWS. Sedangkan untuk kedalaman perairan kolam Terminal Kendal hingga pintu masuk Terminal Kendal yaitu antara -1,3 mLWS hingga $-4,6 \mathrm{~m}$ LWS. Panjang dermaga penyebrangan Terminal Kendal 110 m, lebar 15 m, dan kedalaman -5 m LWS. Selain itu terdapat fasilitas penunjang lainnya yaitu ruang tunggu penumpang.

\section{ANALISIS DAN PEMBAHASAN}

\section{A. Perhitungan Muatan Zona Industri Jawa Tengah}

Perhitungan muatan zona industri dilakukan seperti yang sudah dijelaskan pada bab konsep dan uraian penelitian. Sehingga didapatkan muatan zona industri sebagai berikut

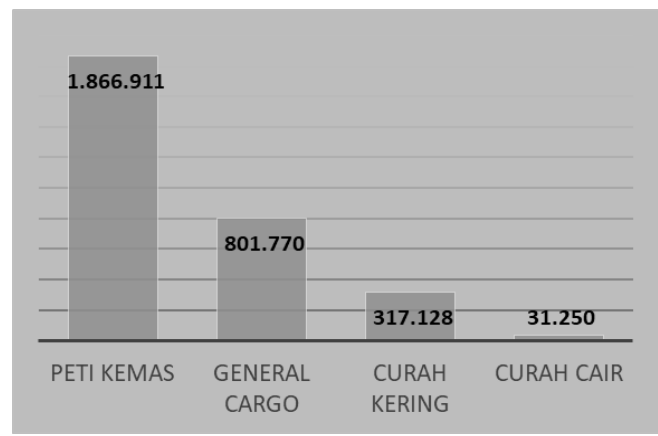

Gambar 4. Total Jumlah Muatan Zona Industri (ton).

Dari tabel tersebut diketahui muatan peti kemas merupakan muatan terbanyak dengan jumlah 1,8 juta ton. Sedangkan untuk muatan curah kering berada pada posisi ketiga terbanyak yaitu sebesar 317 ribu ton.

\section{B. Perhitungan Kapasitas Pelabuhan Tanjung Emas}

Kapasitas pelabuhan dapat ditunjuk dilihat dari kapasitas demaga dan kapasitas penumpukan. Kapasitas dermaga dalam setahun didapatkan dari perkalian produktivitas alat, jumlah alat, dan jam operasional dalam setahun. Sedangkan perhitungan kapasitas lapangan penumpukan peti kemas diperoleh dari perkalian luas lahan yang digunakan peti kemas dalam setahun, rata-rata lama penumpukan peti kemas dalam setahun,dan tinggi tumpukan peti kemas. Kapasitas terkecil diantara keduanya akan menjadi kapasitas dari pelabuhan tanjung emas. Kapasitas penumpukan muatan curah kering dihitung dikarenakan di Pelabuhan Tanjung Emas, muatan curah kering langsung dibongkar dari kapal ke truk maupun sebaliknya. Berikut adalah perhitungan kapasitas dermaga dan lapangan penumpukan Pelabuhan Tanjung Emas.

Tabel 3.

Kapasitas Dermaga Pelabuhan Tanjung Emas

\begin{tabular}{lccc}
\hline \hline \multicolumn{1}{c}{ Faktor } & $\begin{array}{c}\text { Dermaga } \\
\text { Peti Kemas }\end{array}$ & $\begin{array}{c}\text { Dermaga Curah } \\
\text { Kering }\end{array}$ & Satuan \\
\hline Produktivitas Alat & 25 & 100 & $\begin{array}{c}\text { box/jam } \\
\text { ton/jam }\end{array}$ \\
Jumlah Alat & 23 & 3 & \\
Waktu operasional & 7.665 & 7.665 & Jam \\
setahun & & 2.299 .500 & ton/tahun \\
Kapasitas Dermaga & 66.110 .625 & &
\end{tabular}


Tabel 4.

Lapangan Penumpukan Peti Kemas

\begin{tabular}{lcc}
\hline \hline \multicolumn{1}{c}{ Faktor } & $\begin{array}{c}\text { Lapangan Penumpukan } \\
\text { Peti Kemas }\end{array}$ & Satuan \\
\hline Luas Efektif & 203.990 & $\mathrm{~m} 2$ \\
Luas Muatan & 15 & $\mathrm{~m} 2$ \\
Tinggi Tumpukan & 3 & $\mathrm{M}$ \\
Lama Penumpukan & 1 & jam \\
Hari Kerja 1 Tahun & 365 & jam \\
Kapasitas Penumpukan & 14.891 .270 & TEUs/tahun \\
\hline \hline
\end{tabular}

Kapasitas dermaga peti kemas kemudian dikonversi menjadi satuan TEUs/tahun sehingga didapatkan kapasitas dermaga peti kemas Pelabuhan Tanjung Emas adalah 4.407.375 TEUs/tahun. Jika dibandingkan dengan kapasitas lapangan penumpukan maka kapasitas yang menjadi kapasitas pelabuhan tanjung emas adalah kapasitas dermaga yaitu untuk peti kemas sebesar 4.407.375 TEUs/tahun dan muatan curah kering sebesar 2.299.500 ton/tahun.

\section{Klusterisasi Kapal}

Klusterisasi kapal dilakukan berdasarkan histori sarat kapal peti kemas dan curah kering yang pernah singgah di Pelabuhan Tanjung Emas. Batas sarat kapal maksimal di Terminal Kendal adalah $4 \mathrm{~m}$ karena sarat maksimal Terminal Kendal adalah 5 m. Sedangkan sarat kapal maksimal di Pelabuhan Tanjung Emas adalah 11 karena sarat maksimal pelabuhan adalah $12 \mathrm{~m}$.

Klusterisasi kapal dibagi menjadi tiga yaitu kapal ukuran kecil, kapal ukuran sedang, dan kapal ukuran besar. Batasan untuk kapal kecil berdasarkan sarat terkecil diantara Pelabuhan Tanjung Emas dan Terminal Kendal yaitu sebesar 4 m, namun dalam hal ini diambil sarat 4,9 m karena tidak terdapat kapal peti kemas yang memiliki sarat dibawah $4 \mathrm{~m}$. Kapal yang diambil sebagai sampel untuk kluster kapal kecil muatan peti kemas adalah MV Coastal Venture yang memiliki sarat $5 \mathrm{~m}$.

Setelah dilakukan analisis load factor yang memenuhi agar kapal dapat masuk ke Terminal Kendal, didapatkan bahwa maksimal load factor kapal tersebut adalah 70\%. Kemudian untuk batas atas dari kluster kapal besar adalah sarat maksimal dari Pelabuhan Tanjung Emas dan Terminal Kendal yaitu 10,9. Dari beberapa pertimbangan sarat pelabuhan maka ditetapkan untuk kluster kapal kecil memiliki sarat dari $2-4,9$ m, kapal sedang 5-7,9 m, dan kapal besar $8-10,9 \mathrm{~m}$. Berikut adalah spesifikasi masing-masing kluster kapal.

Tabel 5.

Spesifikasi Kluster Kapal

\begin{tabular}{|c|c|c|c|c|c|c|}
\hline Kluster & Nama kapal & $\begin{array}{l}\text { Tipe } \\
\text { Kapal } \\
\end{array}$ & $\begin{array}{l}\text { DWT } \\
\text { (ton) }\end{array}$ & $\begin{array}{l}\text { LPP } \\
(\mathrm{m})\end{array}$ & $\begin{array}{c}\mathrm{B} \\
(\mathrm{m})\end{array}$ & $\begin{array}{c}\mathrm{T} \\
(\mathrm{m})\end{array}$ \\
\hline \multirow{2}{*}{ Kecil } & $\begin{array}{l}\text { KM Permata } \\
\text { Hati }\end{array}$ & $\begin{array}{l}\text { Curah } \\
\text { Kering }\end{array}$ & 1.287 & 60 & 11 & 4 \\
\hline & $\begin{array}{l}\text { MV Coastal } \\
\text { Venture }\end{array}$ & $\begin{array}{c}\text { Peti } \\
\text { Kemas }\end{array}$ & 1.478 & 121 & 18 & 5 \\
\hline \multirow{2}{*}{ Sedang } & KV Simore & $\begin{array}{l}\text { Curah } \\
\text { Kering }\end{array}$ & 9.488 & 137 & 23 & 7 \\
\hline & $\begin{array}{l}\text { MV Meratus } \\
\text { Medan } 1\end{array}$ & $\begin{array}{c}\text { Peti } \\
\text { Kemas }\end{array}$ & 15.742 & 126 & 21 & 8 \\
\hline \multirow{2}{*}{ Besar } & $\begin{array}{l}\text { MV Vega } \\
\text { Aquarius }\end{array}$ & $\begin{array}{l}\text { Curah } \\
\text { Kering }\end{array}$ & 56.865 & 190 & 32 & 10,9 \\
\hline & MV HS.Onore & $\begin{array}{c}\text { Peti } \\
\text { Kemas }\end{array}$ & 37.465 & 133 & 16 & 10,9 \\
\hline
\end{tabular}

\section{Penentuan Hinterland Pelabuhan}

Penentuan hinterland ditinjau berdasarkan biaya transportasi laut yang telah dihitung sebelumnya. Sehingga didapatkan hinterland pelabuhan untuk tiap pengiriman pada maisng-masing skenario

1. Skenario 1

Skenario 1 didapatkan bahwa biaya satuan transportasi melalu Terminal Kendal jauh lebih murah jika melalui Pelabuhan Tanjung Emas. Berikut adalah selisih biaya satuan transportasi dengan biaya trasportasi melalui Pelabuhan Tanjung Emas lebih rendah untuk semua muatan dari semua pelabuhan asal ke semua zona industri tujuan

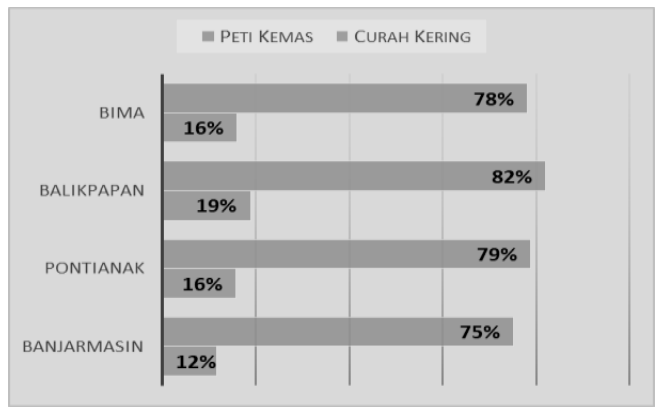

Gambar 5. Persentase Selisih Biaya Satuan Pelabuhan Tanjung Emas.

Sehingga total muatan yang berpotensi menjadi muatan Pelabuhan Tanjung Emas untuk muatan curah kering sebesar 3.805.541 ton dan untuk muatan peti kemas sebesar 1.120.147 ton. Namun potensi arus muatan curah kering lebih besar daripada kapasitas Pelabuhan Tanjung Emas yaitu 2.299.500 ton. Sehingga muatan curah kering sebesar 1.506.041 ton perlu dipindahkan ke Terminal Kendal. Muatan yang berpindah ke Terminal Kendal adalah muatan milik zona industri yang memiliki selisih biaya pengiriman terkecil antara melalui Pelabuhan Tanjung Emas dan Terminal Kendal. Zona industi tersebut adalah Kabupaten Cilacap, Kabupaten Tegal, dan Kabupaten Wonogiri dengan persentase selisih berturut-turut $71 \%, 76 \%, 76 \%$. Total muatan dari ketiga zona industri tersebut sebesar 1.739.995 ton yang mana jumlah muatan tersebut sudah melebihi jumlah muatan yang perlu dialihkan ke Terminal Kendal dan tidak kurang dari jumlah muatan yang perlu dialihkan. Sehingga dapat digambarkan hinterland Pelabuhan Tanjung Emas dan Terminal Kendal sebagai berikut

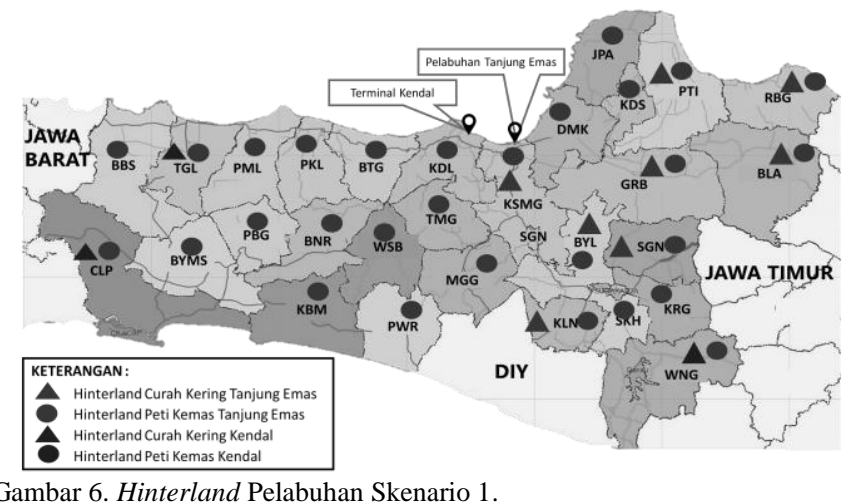




\section{Skenario 2}

Hasil dari analisis skenario 2, rata-rata biaya total pengiriman semua jenis muatan dan asal tujun melalui Pelabuhan Tanjung Emas $31 \%$ lebih murah daripada melalui Terminal Kendal. Rincian selisih total biaya dari masingmasing pelabuhan asal dengan biaya total transportasi barang lebih murah melalui Pelabuhan Tanjung Emas ditampilkan pada grafik berikut

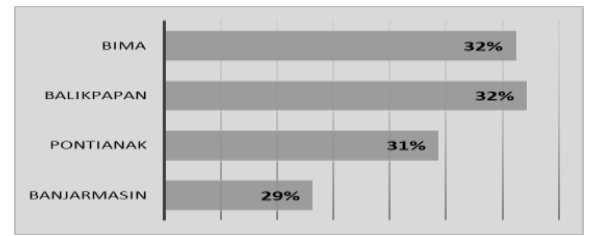

Gambar 7. Persentase Selisih Biaya Satuan

Karena pada skenario 2 lebih mahal daripada skenario 1 maka hinterland dari masing-masing pelabuhan menggunakan hinterland skenario 1 .

3. Skenario 3

Dari hasil analisis biaya transportasi didapatkan bahwa biaya pengiriman muatan curah kering ke tujuan Tegal ratarata lebih murah $4 \%$ melalui Terminal Kendal. Sedangkan zona industri tujuan lain $7 \%$ lebih murah melalui Pelabuhan Tanjung Emas. Untuk muatan peti kemas biaya pengiriman ke tujuan Kabupaten Banyumas, Kabupaten Batang, Kabupaten Brebes, Kabupaten Kendal, Kabupaten Pekalongan, Kabupaten Pemalang, Kabupaten Purbalingga, Kabupaten Tegal, Kabupaten Temanggung, dan Kabupaten Wonosobo lebih murah 9\% melalui Terminal Kendal. Sedangkan untuk tujuan zona industri yang lain lebih murah $14 \%$ melalui Pelabuhan Tanjung Emas. Berikut adalah gambaran dari hinterland pelabuhan untuk skenario 3 .

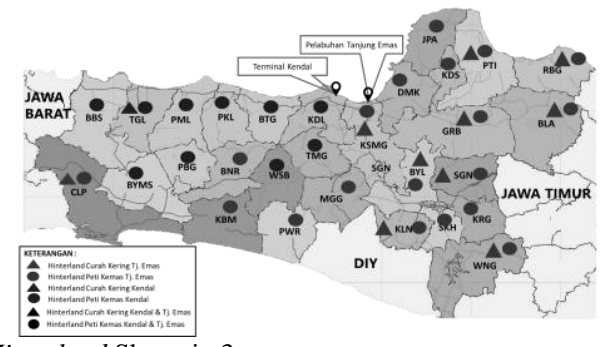

Gambar 8. Hinterland Skenario 3

\section{KESIMPULAN/RINGKASAN}

Dari hasil penelitian dan perhitungan yang telah dilakukan, maka diperoleh beberapa kesimpulan sebagai berikut:

1. Kondisi eksisting muatan curah kering dan muatan peti kemas

a. Jumlah produksi muatan peti kemas di Provinsi Jawa Tengah pada tahun 2016 sebesar 1.120.147 TEUs yaitu 67\% dari keseluruhan muatan sedangkan matan curah kering sebesar 3.805 .540 ton yaitu sebesar $12 \%$ dari keseluruhan muatan.

b. Rata-rata jumlah muatan peti kemas Pelabuhan Tanjung Emas tahun 2016 sebesar $61 \%$ sedangkan untuk muatan curah kering sebesar $19 \%$

2. Dari sisi biaya transportasi laut, Terminal Kendal tidak memberikan dampak terhadap industri di Jawa Tengah dengan pola pengiriman barang skenario 1 dan skenario 2 . Namun dengan pola pengiriman barang skenario 3, Terminal Kendal memberikan dampak penurunan biaya transportasi yang relatif kecil yaitu untuk muatan curah kering tujuan Kabupaten Tegal terjadi penurunan biaya sebesar $4 \%$ dan untuk muatan peti kemas sebesar $9 \%$ dengan tujuan zona industri di Kabupaten Banyumas, Kabupaten Batang, Kabupaten Brebes, Kabupaten Kendal, Kabupaten Pekalongan, Kabupaten Pemalang, Kabupaten Purbalingga, Kabupaten Tegal, Kabupaten Temanggung, dan Kabupaten Wonosobo.

\section{UCAPAN TERIMA KASIH}

Penulis mengucapkan terima kasih kepada PT. Pelindo III Cabang Tanjung Emas, Disperindag Jawa Tengah.

\section{DAFTAR PUSTAKA}

[1]

[2]

[3]
BPS Jawa Tengah, "BPS Jawa Tengah,” Jawa Tengah, 2017. Dinas Perhubungan Provinsi Jawa Timur, "Rencana Induk Pelabuhan Nasional (RIPN) Pelabuhan Tanjung Emas, Jawa Tengah," Semarang, 2013.

Kementerian Perindustrian Indonesia, "Pedoman Teknis Kawasa Industri. Indonesia, Patent No. 35/M-IND/PER/3/2010,” 2010.

S. Chopra and P. Meindl, Supply Chain Management Strategy, Planning, And Operation, 5th ed. Prentice Hal, Inc, 2013. 